\title{
Web Engagement Strategies In Business, Government And Education Sector: Review
}

\author{
Norita Ahmad', Aziman Abdullah² \\ ${ }^{1}$ Kolej Komuniti Paya Besar, Jalan Maran-Gambang, 26600 Gambang, Pahang, Malaysia. \\ 2Faculty Of Computing, Universiti Malaysia Pahang, 26600 Pahang, Malaysia
}

\begin{abstract}
Web engagement is a user experience related to emotional, cognitive and behavioural interaction that connect to the goals and interests of the customers. There are seven (7) engagement metrics listed that used to measure web engagement. However, not all of these engagement metrics will help to achieve the objectives because each website have different purpose. There are various web engagement strategies used in business, government and education sectors that has their own way of engaging the web to ensure their success. In business sector, positive communication and experience with customers can make the customers stay long with the brand. In government, most of the services provided are to facilitate the people and to maintain the trust and support of the people. The E-Government 2.0 model was presented with an additional element of Web 2.0 technology. In education, Learning Management System (LMS) and Massive Open Online Courses (MOOCs) are some of the approach in online learning. There are four (4) main features of online learning that are distance learning, connectivity and involvement, support and flexibility control to ensure the continuity of online learning. This reviewing will lead having in attention the aim of developing high-performance in online engagement.
\end{abstract}

ARTICLE HISTORY

Revised: 29 July 2020

Accepted: 12 Nov 2020

KEYWORDS

Web engagement

E-Government

Online Learning

\section{INTRODUCTION}

Web engagement is important to build trust and loyalty, inspire emotions and increase attention. It is related to a user experience that is connected to emotional, cognitive and behavioural interaction. However, different types of websites have different ways to measure engagement. Considering some of the engagement metrics may help users to stay in touch with the brand or services. To improve user engagement, providing quality information to the right people at the right time is the best rule.

The atmosphere in digital information has become tougher and, in order to achieve a strong market volume, the content needs to be fully interactive. The measurement of web engagement that is not carried out can lead to unprofitable businesses. Therefore, this paper intends to increase the engaged audience and create memorable experiences by applying the web engagement strategies listed in the business, government and education sector. This article combines web engagement strategies from the three sectors that are rarely found in other articles as most articles focus on one area only.

The significance of this paper is discussing potential strategies and delivery methods in different sectors that are very relevant in this current digital revolution. The purpose of this paper review is to show the importance to calculating the involvement of the website on a regular basis for the smooth running of the company as the primary aim of starting a company is to sell a product or service.

The remainder of this paper is organized as follows: Section 2 briefly presents an overview of the definition of web engagement. Section 3 explains the web engagement metrics to measure the web engagement. Section 4 provides the web engagement strategies in business, government and education sectors. In the last section of this paper, it concludes the findings with the similarities and differences of web engagement strategies in all sectors.

\section{DEFINITION OF WEB ENGAGEMENT}

Web engagement or also known as online engagement is typically derived from interactions such as click-through, download, comments, likes and subscribe on a product, services or advertisement. According to literature [1], site engagement is mostly measured through user behaviour with the depth of interaction with a site. This includes clickthrough rates, number of page views, time spent on a site (dwell time), how often users return to a site and number of users per month. Dwell time has proven to be a meaningful measure of site engagement because the more engaged users are in the web search, the more likely they are to underestimate the passage of time [2].

For instance, user engagement refers to how frequently and how long a user interacts with the website, application, or other product. It matters because engagement is directly connected to emotional, cognitive and behavioural connections 
that show a person's level of interest [3]. Usually, the more time a person spends on a product, the more he or she is invested in it. This is a challenge to identify which aspects of the online interaction influence user engagement the most. If the user's connection with that product was increased, it will bring more opportunity to earn sales and profit.

Moreover, user engagement is the quality of the user experience that emphasises the positive aspects of the interaction [4]. In this case, users are being motivated to engage with time, attention and emotion that brings the factor of successful web applications. While other literature [5] proposed that engagement as the collective experiences that readers or viewers have with a media brand or channel-centred such as newspapers, magazines, TV programs, or web sites. In this context, an experience is a specific set of beliefs that consumers have about how some media brand fits into their lives. So, this media engagement and experiences should be powerful enough to grab the audience's attention when engaged with that brand.

Furthermore, other researchers [6] define engagement in online brand communities as a behavioural manifestation and conceptualize consumer engagement. Online brand community is a type of social media platform by a company to help consumers of that company and build relationships with each other through online communication. This online brand community can affect customers' perceptions and contributes substantial marketing value to the company.

Table 1. Various Summaries of Engagement Definition

\begin{tabular}{|l|l|}
\hline \multicolumn{1}{|c|}{ Authors } & \multicolumn{1}{c|}{ Engagement Definition } \\
\hline$[5]$ & $\begin{array}{l}\text { Engagement as the collective experiences that readers or viewers have with a media } \\
\text { brand or channel-centred. }\end{array}$ \\
\hline$[4]$ & $\begin{array}{l}\text { User engagement is the quality of the user experience that emphasises the positive } \\
\text { aspects of the interaction. } \\
\text { User engagement is the emotional, cognitive, and behavioural experience of a user with } \\
\text { a technological resource that exists, at any point in time and over time. }\end{array}$ \\
\hline$[2]$ & $\begin{array}{l}\text { Site engagement is mostly measured through user behaviour with the depth of interaction } \\
\text { with a site. }\end{array}$ \\
\hline$[1]$ & $\begin{array}{l}\text { User engagement is directly connected to emotional, cognitive and behavioural } \\
\text { connection that show a person's level of interest. }\end{array}$ \\
\hline$[3]$ & \begin{tabular}{l} 
Engagement refers to the degree of and depth of visitor interaction on a website against \\
a defined set of goals. \\
\hline$[7]$
\end{tabular} \\
\hline$[6]$ & $\begin{array}{l}\text { Engagement in the online brand community as a behavioural manifestation and } \\
\text { conceptualize consumer engagement. }\end{array}$ \\
\hline
\end{tabular}

Table 1 shows the various summaries of engagement statement definition by some of the researchers over the years. From the summary definition table, it shows the evolution of web engagement definition which is quite relevant between researchers. It can be concluded that web engagement is a user experience related to emotional, cognitive and behavioural interaction that connect to the goals and interests of the customers.

\section{MEASURING WEB ENGAGEMENT}

Ordinally to achieve better website engagement, the website usage can be tracked using some tools of web analytics such as Google Analytics. Web analytics can help web application management by collecting web traffic data and doing some analysis [8]. Web traffic analytics is very important to show user's interest and their behaviour that can be used to improve delivery of the service. Delivering high-quality content to attract the right users can help to make a right decision and also to maintain a relationship with users on the site.

Web engagement is measured using engagement metrics such as number of unique users, number of page views and the average time spent on a website [4]. This metric can then be used by website owners as a performance indicator and a benchmark for user engagement. Engagement metrics that show classification and rank information can be used to compare among websites and promote a specific category to the advertisers to get high returns [7].

Creating a simple website layout or template that fit the device and the platform, easy navigation, and readable content with right font size can create an interactive communication between the user and the website. Using digital media elements such as infographic images and flash videos on advertising also will improve website engagement and gives advantage to advertisers that leads to higher sales [5]. Thus the new trend of engagement for advertising space through online media with highly engaged readers was increased.

There is no one size fit all model for measuring user engagement for a website because different user engagement models are used for different types of websites. For example, a news site or blog that depends on time, longer period of time spent reading articles, the more opportunity there is for monetization. These content-based sites should focus more heavily on time spent by readers that can be measured by dwell time metrics [3]. Meanwhile, for social media platforms, it often involves checking statuses or posting quick updates, so the length of engagement time could be relatively short. But for news apps or music apps, it should be more time allocated. 
Some of the user engagement metrics that could be useful to follow are concluded as Website Visitors, Frequency of Visits, Core User Actions, Pages Per Session, Average Session Duration, Bounce Rate and Visitors Recency [7]. The explanation for each metric is shown in Figure 1. Metrics which are relevant to the type of website developed are chosen because it will help to improve website traffic, also to understand user interest and interaction style [4]. It is not necessary that all of these engagement metrics listed will help to achieve the objectives because it may be slightly different, for example in mobile applications.

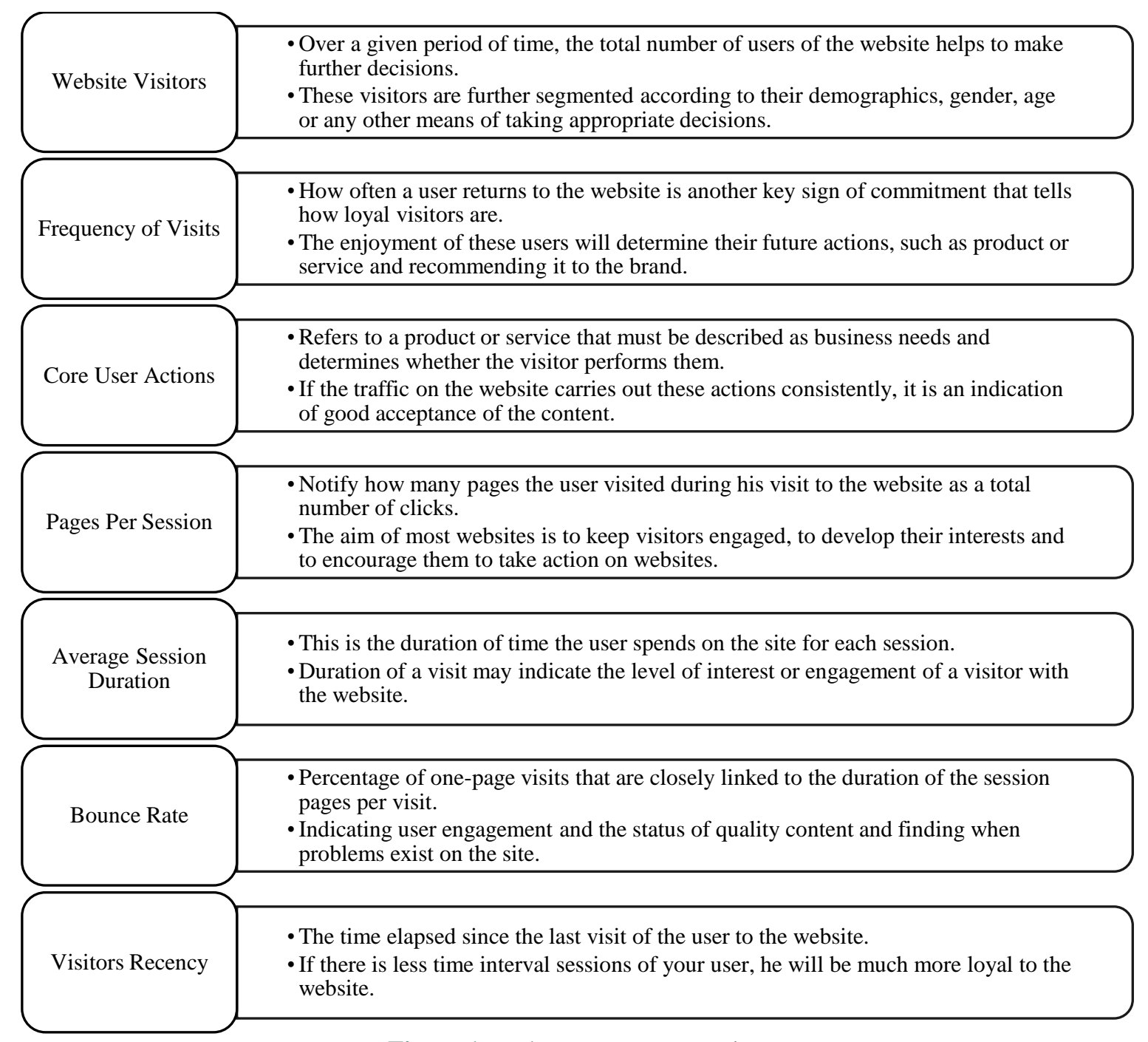

Figure 1. Web Engagement Metrics.

In the age of technological advances, the use of the web is a major necessity and has become a key requirement for promoting an agency or company to the public. People use the Internet to get all the information they needed related to services, products or anything just on their fingertips. It is easy to measure web engagement because positive affect and fun experienced during an online session will bring the users to coming back to discover and explore more [2]. Therefore, business, government and education are no exception to using online platforms to attract consumers and users. These different strategies in each sector will be explained in the next subtopic.

\section{WEB ENGAGEMENT STRATEGIES}

\section{Business Sector}

In a context of business and marketing, user engagement is often referred to as customer engagement that refers to an individual's response to some type of offering, such as a product, a service or a website [9]. The objectives of customer engagement strategies either to increase sales or to acquire new customers and build brand awareness must be clearly prioritized. However, the nature of a product or service gives different ways to measure and improve user engagement. For e-commerce websites, users who browse more frequently to find what they're looking for and then make purchases will be considered as more engaged. The website engagement is important not only helps to sell products or services, but also affects customers' perceptions and actions that makes customers stay for a long time [6]. 
There are several strategies that can be used to engage today's technology-empowered customers that will turn more interactions into transactions. There are six (6) strategies that are listed in following Figure 2.

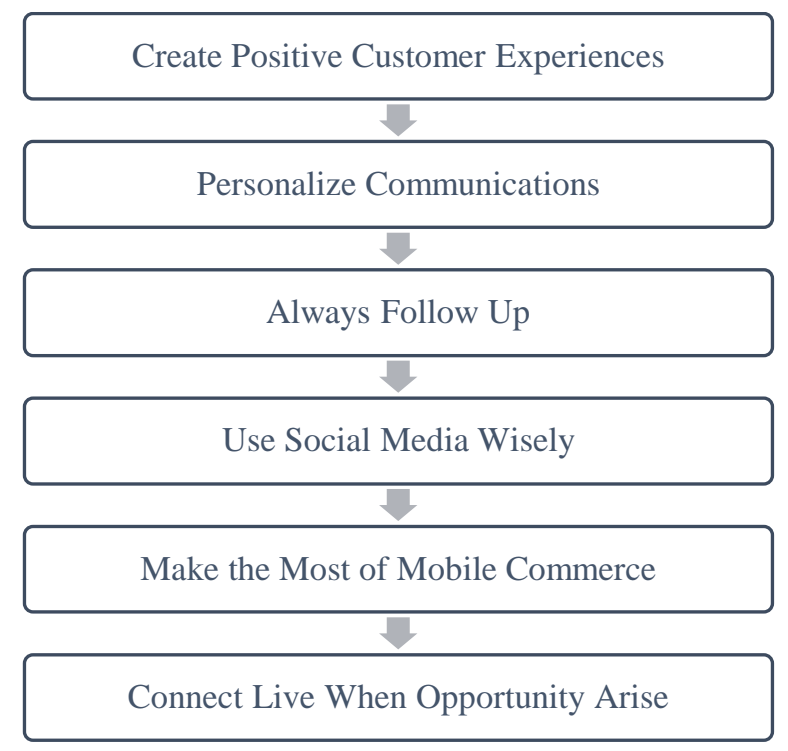

Figure 2. Web Engagement Strategies in Business.

Customers can compare product prices by doing online reviews that describe different product features. They can post reviews after making the purchase which can distract the latest promotion by other competitors. According to literature [6], online reviews to get customer feedback will influence sales that affects retailers' performance and offer. It is also cost-effective and an easy way to collect product reviews from customers. This is supported by other researchers [10] that mentioned user engagement behaviors in online communities will increase the sales and brand loyalty. Providing excellent customer service also is one of the best ways to create positive shopping experiences. Therefore, the customer service team must solve problems faced by customers quickly and wisely.

Personalizing communications is important to create ongoing relationships with the brand and target promotions. For example, asking personal preferences of the customers whether they'd like to receive offers and promotion details through an email communication. Others are like sending a polite reminder about items in an abandoned shopping cart, giving care instructions on a recently purchased item, or thanking customers for their feedback and reviews. A researcher [11] proposed that by providing digital content marketing such as videos, articles, blogs, and newsletters can cultivate customer engagement, trust and value. This can help to learn more about customers' shopping preferences and interests which has an influence on user affective response, including satisfaction and overall attitude towards the website [12].

Always follow up is one of the customer engagement efforts that focus to attract loyal customers. It starts from sending notification or transactional email to inviting customers to leave feedback or review their purchases. The communications done with customers after checkout can have a big impact on whether they want to become a repeat customer and recommend to their friends or not. Maintaining a long-term relationship with customers and making them happy is an important business strategy. This focuses on brand loyalty outcomes which is the attachment to certain brands and companies only [10]. Furthermore, retailers can extend special offers to their social networks and give rewards to loyal customers to participate in private sales held by them.

Currently, social media engagement like Facebook, Twitter, and Instagram can reduce the communication gap between consumers and companies to become a domination of the entire commercial market. These social media platforms have become an effective communication tool that provides a source of information to users [13]. Customers engaged in the social media platforms will spread brand information that contribute to develop corporate reputation and image. The conversation needs to engage both sides; customers and companies which contribute to the success. According to literature [14], this online brand community engagement based on experiences will have a positive influence because the content included in the communication is relevant, personable and provides comments on topics that tackle other customer's interests.

The trend of mobile communication presents significant challenges and opportunities for retailers that become one of the tools for engaging customers. This makes retailers optimize their sites for mobile applications to get engaged with customers on their mobile phones and tablets. Nowadays, users spend more time on their smartphone so this opportunity is used by retailers to engage customers via social, gaming, lifestyle, productivity, and branded apps. Mobile shopping has become increasingly relevant and has its own implications on customer behavior and retailer strategies [15]. The mobile apps developed should be optimized for customers to share products and make purchases through real-time mobile shopping.

As online sales replace the in-store sales, digital interactions with customers are increasingly as consumers spend more time online on their mobile devices. Webinars, webcasting, community forums, live events and live chat are face to face interactions that present an opportunity to engage personally with customers and create long lasting impressions. For 
example, fashion retailers can host virtual fashion shows online; vitamin retailers can host live webinars on health topics; software retailers can host how-to events and offer online communities. This integrated marketing communication is more significant because of the reduced cost effectiveness and can be accessed from anywhere [16].

As a summary, all the web engagement strategies in business that are briefly explained before can contribute to increase sales and give benefits in the marketing field. Regardless of which strategy is implemented, always to catch customers' attention first to get in touch with a certain target group. It's up to the retailer to use which strategy depends on the behavior of potential buyers and how to understand these actions. Most important is both customers and sellers have a positive impact in fulfilling their needs and wishes. The global phenomenon in digital communication nowadays gives both sides the opportunity to use ICT in the best and proper way. Hence, it's becoming very important to measure these web engagement strategies regularly for a smooth running of the business.

\section{Government Sector}

Electronic Government initiative or E-Government has been applied to transform administrative process and service delivery through the use of Information Communication Technology (ICT) and multimedia. E-Government is defined as a way for governments to use ICT applications, to provide citizens and businesses with easy access to government information and services [17]. A researcher [18] has proposed that the objectives of E-Government application are to improve the quality and efficiency in the delivery of government services to all citizens. More and more governments are using ICT and its application such as web portal and web-based system to provide services and transactions between government and business, government and citizen, government and employee and among different units of government.

There are several benefits of E-Government application as discussed by [18]. If the implementation is designed properly, it can increase citizen trust to government other than surely can save cost to people, business community and government itself. Websites can be cheaper and cost effective to owners and users in a way to exchange information and publish information on regulations, procedures and other aspects of an organization's work. Number of enquiries staff can be reduced as the website already provides answers to the most common Frequently Asked Questions (FAQ). It is also a quicker way to introduce changes and release news or other information to the public. The website will publish an article or infographic immediately instead of using printed material that will be costly that enables fast response from others. E-Government also can provide better ways to manage information with database usage compared to traditional ways. Any online transactions can be done quickly because the official manual input and paper-based forms are not needed to be prepared. According to [17], implementation of e-Government brings goodness such as providing less corruption, increased transparency, greater convenience, revenue growth, and of course cost reductions.

In Malaysia, the Malaysian Administrative Modernisation and Management Planning Unit (MAMPU) had justified the e-Government model strategy to engage citizens in ICT as shown in Figure 3. These three (3) domains that are government, citizen and business are the major contribution to the successful implementation of e-Government in Malaysia. It includes Government to Governments (G2G), Government to Citizens (G2C), Government to Business (G2B) and Government to Employees (G2E) [18]. Table 2 describes each domain in e-Government delivery model with an example of implementation.

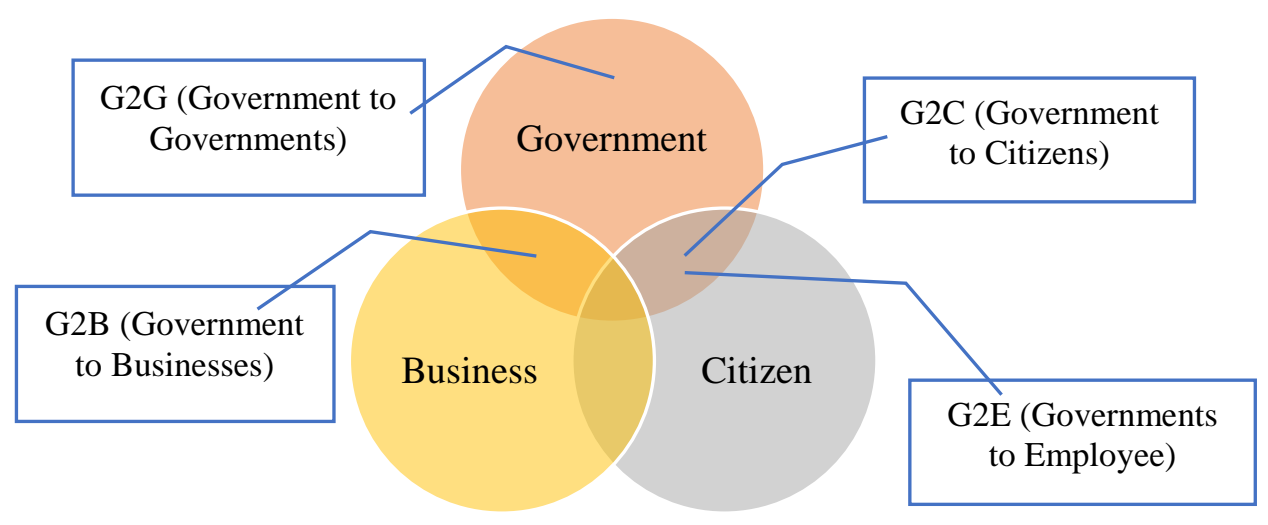

Figure 3. E-Government Model Strategy according to MAMPU. 
Table 2. Description of E-Government Delivery Model.

\begin{tabular}{|c|c|c|c|}
\hline No & Model & Description & Example Application \\
\hline 1 & $\begin{array}{l}\text { Government } \\
\text { to } \\
\text { Governments } \\
\text { (G2G) }\end{array}$ & $\begin{array}{l}\text { - G2G refers to the online } \\
\text { relationship between government } \\
\text { organizations, departments, } \\
\text { agencies and even other } \\
\text { governments that improve inter- } \\
\text { government organizational } \\
\text { processes by cooperation and } \\
\text { coordination. } \\
\text { - G2G facilitates the sharing of super- } \\
\text { government databases, resources } \\
\text { and capabilities, enhancing the } \\
\text { efficiency and effectiveness of } \\
\text { processes. }\end{array}$ & $\begin{array}{l}\text { - Generic Office Environment (GOE) is an electronic } \\
\text { office environment to enhance productivity through } \\
\text { better information management and communications } \\
\text { that enables effective collaboration across agencies. } \\
\text { This GOE provides a fully integrated, distributed and } \\
\text { scalable paperless environment via an open system } \\
\text { platform. } \\
\text { - GOE enables transparency and timely decision making } \\
\text { to ensure the right information gets to the right people } \\
\text { at the right time. It could be able to check electronic } \\
\text { mail, meeting schedule, and filtered news, accessing } \\
\text { documents online and assigning tasks. }\end{array}$ \\
\hline 2 & $\begin{array}{l}\text { Government } \\
\text { to Citizens } \\
(\mathrm{G} 2 \mathrm{C})\end{array}$ & $\begin{array}{l}\text { - } \mathrm{G} 2 \mathrm{C} \text { is the interaction between } \\
\text { government and citizens that allows } \\
\text { citizens to access government } \\
\text { information and services from } \\
\text { everywhere. } \\
\text { - G2C is focused on customer centric } \\
\text { and integrated electronic services } \\
\text { where public services can be } \\
\text { provided as a one-stop shop } \\
\text { concept. People who are involved in } \\
\text { multiple agencies can carry out a } \\
\text { variety of tasks without needing to } \\
\text { initiate contacts with each } \\
\text { individual agency. }\end{array}$ & $\begin{array}{l}\text { - Electronic Services Directory (e-Services) through } \\
\text { web sites and kiosk machines that enables citizens and } \\
\text { businesses to conduct transactions through a one-stop } \\
\text { service window. } \\
\text { - The benefits of e-Services are providing choice of } \\
\text { multiple delivery channels, easy accessibility and } \\
\text { convenience offered by extended hours and multiple } \\
\text { services via a single window of access that can } \\
\text { enhance efficiency and effectiveness of government } \\
\text { services. } \\
\text { - Examples of e-Services are from the Road Transport } \\
\text { Department, police, utility bill payment and other } \\
\text { government services from ministries. }\end{array}$ \\
\hline 3 & $\begin{array}{l}\text { Government } \\
\text { to Business } \\
(\mathrm{G} 2 \mathrm{~B})\end{array}$ & $\begin{array}{l}\text { - G2B includes various services } \\
\text { exchanged between government } \\
\text { and the business sectors that can } \\
\text { bring significant efficiencies to both } \\
\text { governments and businesses. } \\
\text { - The services offered through G2B } \\
\text { transactions also play a significant } \\
\text { role in business development, } \\
\text { specifically in small and medium } \\
\text { enterprises (SME). } \\
\text { - Online transactions with the } \\
\text { government will simplify regulatory } \\
\text { processes, reducing transaction } \\
\text { costs and help businesses to become } \\
\text { more competitive. }\end{array}$ & $\begin{array}{l}\text { - eProcurement (EP) is a web-based system that allows } \\
\text { the government to conduct procurement activities } \\
\text { electronically via desktops computing. It enables all } \\
\text { suppliers in Malaysia to make an online register into } \\
\text { the system anytime, publish product or services } \\
\text { catalogues on EP and receive orders from the } \\
\text { government. } \\
\text { - Then, the government will browse catalogues and } \\
\text { place orders online or request for tender on EP for new } \\
\text { supplies and awards contracts to suppliers either for } \\
\text { direct purchase, quotation or tendering. } \\
\text { - The benefits of this EP system are processing } \\
\text { procurement transactions become faster, the } \\
\text { governments become a smart buyer and of course } \\
\text { saves cost to the government and suppliers. }\end{array}$ \\
\hline
\end{tabular}


4 Government to Employees (G2E)
- G2E refers to the relationship between government and its employees only is to serve employees and offer some online services such as updating service records, applying annual leave, filling in annual works targets and reviewing salary payment records.

- G2E also gives employees the possibility to access other services information regarding compensation policies and retirement benefit, training and learning opportunities and others.
- Human Resource Management Information System (HRMIS) was developed to provide full management for human resource functionality and manage its human capital.

- HRMIS provides a single interface for all government employees to manage the personal record, communication and behavioral management. Other than that, this system also will update benefits and reward, performance and career development.

- HRMIS enables horizontal integration and streamlined human resource functions to facilitate effective human resource management.

According to researcher [19], The availability of ICT infrastructure, trust, people's attitude, quality of information and the support in using the e-Government applications are all cause the public to become the users of the e-Government system. This statement is supported by the research from [20] that mentioned people who have higher information literacy will influence trust in the government website. However, research done by [21], showed that inadequate technical infrastructure, lack of skills, insufficient financial resources, unclear ICT policy, poor leadership and lack of integration will fail the mission of e-Government. Since implementation of e-Government gives a positive impact to both government and citizens, a proactive role in tackling the problems immediately was taken to enhance the actual use of the eGovernment services.

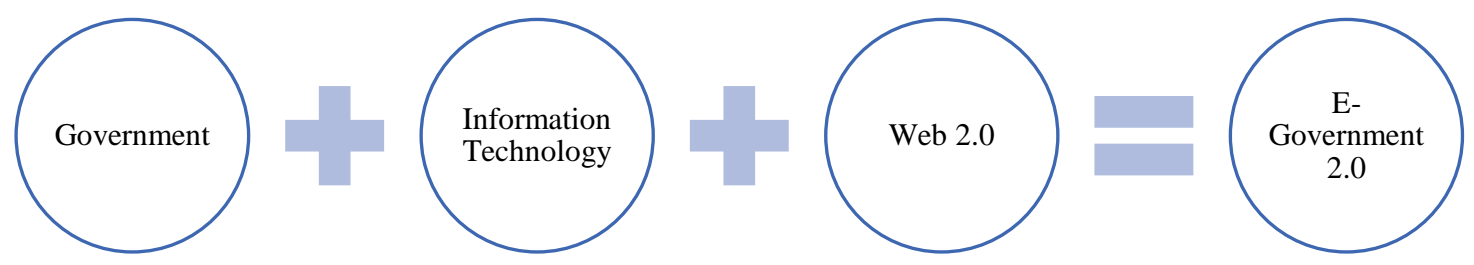

Figure 4. E-Government 2.0 Model.

Currently, the E-Government 2.0 model was presented with an additional element that is Web 2.0 technology as illustrated in Figure 4. As mentioned by literature [22], there are four (4) characteristics of E-Government 2.0 that are society-centered, generating and developing content by the user, openness and transparency and cooperation. Web 2.0 refers to a variety of web sites and applications with easy connection that allow anyone to create and share information and communicate online [22]. The example of Web 2.0 such as hosted services, web applications, video sharing sites, blogs, social networking, microblogging and podcasting. Digital Participatory Platforms (DPP) is a specific kind of collaborative social media between government and citizen that is based on Web 2.0 technology [23]. It includes all the features of social media such as Facebook, YouTube and Twitter that allows the government to generate and share such content which is similar to $\mathrm{G} 2 \mathrm{C}$ relationships.

The implementation of e-Government 2.0 also provides opportunities for people to participate in processes of democratic institutions. As the utilization of technology to enhance the quality of public service delivery [21], government and political parties manage to use social media platforms to get stronger social connection with people and voters [24]. This provides opportunities to the public and organizations to diversify their communication strategy as individuals also using social media to participate in discussing political or civic issues with each other. Thus, citizen engagement through social media platforms such as Facebook and Twitter can reduce the cost of communications and increase citizens' trust on the way of the government [25].

Regarding the citizen engagement, shares and retweets are the most frequent way for citizens to interact with the ministries account in these social media. According to literature [26], city promotion, cultural activities, sport and environmental issues generate higher engagement from citizens. This social media integration influences the communication strategies positively on implementation of government policy that should be considered for future generation needs [25]. However there are several challenges in implementing E-Government 2.0 that are internet accessibility, digital illiteracy, institutional framework challenges, data management, process-related challenges, intraorganizational culture and availability of human resources [23]. But despite these challenges, e-Government 2.0 continues to grow and be adapted by many countries in the world.

This web engagement strategy in government through implementation of e-Government 2.0 has brought to include digital platforms and advanced technological features for collaboration purposes between local government and citizens. The benefits of applying web 2.0 in governments that are help to improve the policies and offer services through enriching 
government interactions with citizens. Identifying the main causes of limitation of citizen engagement with e-Government must be considered attentively to increase the positive effects of the application e-Government 2.0.

\section{Education Sector}

In higher education, student engagement in learning has a positive significant impact on learning outcomes. As universities have increased their online presence and provided more opportunities for fully-online studies, being focused and engaged in online coursework is required to determine the success of learning [27]. The student's motivation to participate in online education is an important aspect of student engagement to contribute the desired outcomes including high grades and student satisfaction [28]. Students engaged in online coursework need to be self-motivated, independent and responsible learners [29].

The most important elements in online learning are the instructors who need to improve their online teaching effectiveness, instructional designers who want to build engaging online courses and administrators who support staff in order to make sure that these online programs are working successfully [30]. An easy to use online learning environment will have an influence on the student engagement because it includes active learning, collaborative learning, participation and communication between teachers and students.

This online learning environment consists of text materials, images, audio and video, multimedia courseware and other learning resources that makes the learning environment more fun and impactful. Students actively involved in online learning are important that leads to efficiency of the online learning [31]. It is a student-centered learning approach in which students' engagement in learning activities has an important influence on the process and outcomes.

Student engagement when using online learning platforms includes the behavioral engagement, cognitive engagement and emotional engagement [31]. Online learning can provide students quick learning as students can browse the courses, publish their own views and opinions, share their work or resources, submit assignments or projects and participate in forum discussions. As summaries from multiple research, there are four (4) main features of online learning that are described details in Table 3.

Table 3. Features of Online Learning

\begin{tabular}{|c|c|c|}
\hline No & Features & Description \\
\hline 1 & Distance Learning & $\begin{array}{l}\text { E-Learning spread knowledge over a larger number of places and people } \\
\text { which are between students and students, students and teachers and } \\
\text { students and content [32]. } \\
\text { - The interactions that support multidirectional communication can be in } \\
\text { various ways, such as discussion, email and group message. }\end{array}$ \\
\hline 2 & $\begin{array}{l}\text { Connectivity and } \\
\text { Involvement }\end{array}$ & $\begin{array}{l}\text { - Students must respond to given online learning tasks, concentrate on the } \\
\text { learning materials and cooperate with other students in the class. } \\
\text { - Involvement also included sharing information or for posting comments } \\
\text { and others [33]. }\end{array}$ \\
\hline 3 & Support & $\begin{array}{l}\text { - Refers to the external support, such as lecturers guide, peers help, expert's } \\
\text { advice and related software tools. } \\
\text { - Conducting e-Learning by using social-web based tools like blog, social } \\
\text { network and forum help to improve the engagement in active learning [34]. }\end{array}$ \\
\hline 4 & Flexibility Control & $\begin{array}{l}\text { - Online learning creates opportunities for individuals who may have faced } \\
\text { challenges prior to online educational programs [29]. } \\
\text { - This flexibility control enables students to control their learning activities } \\
\text { including schedule of study, selection of learning content and management } \\
\text { of learning activities. }\end{array}$ \\
\hline
\end{tabular}

Learning Management Systems (LMS) that is also commonly referred to as Course Management Systems (CMS) is a web based technology system that has been the leader in online learning since the beginning. With dramatic improvement of the ICT, many academic institutions turn to use new features in learning environments that rely on ICT which make LMS become the most widely used in higher educational technology in a short time [28]. LMS consists of two elements that are a server to perform the base functionality and a user interface that is operated by instructors, students and administrators. 


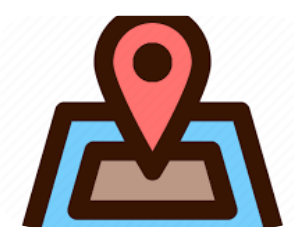

Concept of discarding the physical location

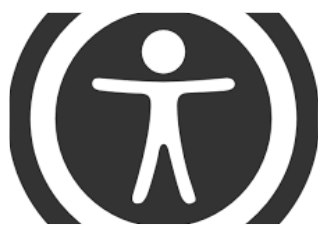

Easy Accessibility

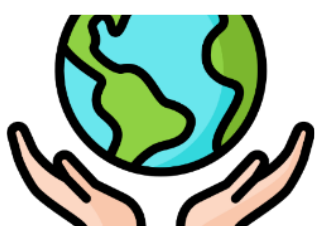

Attractive Environments

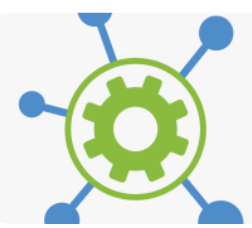

Can be integrated with any missing contents

Figure 5. Common Features of LMS.

According to researchers [35], there are four (4) common features of LMS as illustrated in Figure 5. LMS can be used as an effective tool for students in the same university but different campuses where these students get in one virtual place which enables all their interactions, discussions and feedback. LMS enables the continuing educational process regardless of the location and time. This e-Learning also can include gamification or video games for educational purposes which is an attractive environment for all the students. Sometimes, LMS can be integrated with other common features in order to match the users' requirements.

In addition, LMS are affecting teaching pedagogy and student learning style since it provides access to online learning services at any time which can influence their performance and the final outcomes [36]. Most LMS have increased their accessibility for users to login via various internet browsers or official apps through computers, laptops, smartphone and tablets. The top examples of open source LMS that are currently used in academic education are Moodle, Chamilo, Open edX, Canvas and Totara Learn.

Massive Open Online Courses (MOOCs) is one more free course of online study to a very large number of people where anyone who decides to take a MOOCs simply logs on to the website and signs up to the course. A MOOCs is massive because it attracts tens of thousands of participants per intake with easy accessible and free participation that enables students to make connections with the content and other learners to create and construct knowledge [37]. The course materials can be distributed by lecturers using video clips and downloadable readings, supplemented by discussions and social media activity such as live chat with no restrictions.

MOOCs improve the quality of instruction in online learning courses in higher education because it is free to offer for anyone with an Internet connection [38]. Various universities and academic institutions have been joining in the MOOCs movement because it supports learning environments that allow learners to take high-quality courses offered without any charge. The difference between LMS and MOOCs is LMS is a platform for hosting a course, while a MOOC is the course itself. Along with the benefits of engagement in online learning, there are some strategies that need to be taken in order to improve in online learning. As concluded from other research, there are five (5) ways to improve online learning for students as illustrated in the following Figure 6.

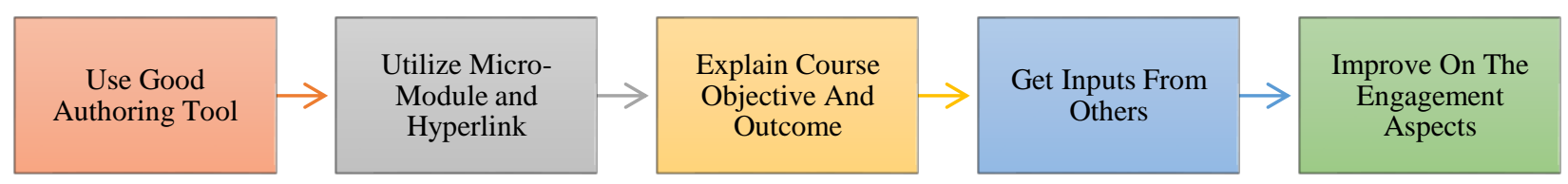

Figure 6. Strategies to Improve in Online Learning.

E-Learning education consists of quality content material in many aspects like texts, images, videos, animations and audio narrations. Proper utilization of the good authoring tools that are available will offer the abilities to design, edit, and share online courses on different platforms, create courses in different formats like text, video, and audio and also generate reports for learning and teaching progress. This multimedia application is used to enhance the educational experience and deliver the learning material to learners with low cost per unit through exploration, discovery and experience [39]. Making full use of these multimedia elements to present the lessons can keep students with the concepts and ideas for a longer time.

To utilize e-Learning at its best, avoid creating huge topics in a single segment because micro modules can transfer information more efficiently than the traditional methods. For most of the modules, the content must be designed to allow students to understand a lesson without depending on the other lessons in the course. This is supported by literature [40] whose proposed that by preparing the teaching materials into smaller sections called micro learning will improve the individual specific results. Hyperlinks can be used to link the sections where the particular topics have been explained to ensure easy navigation and keep a continuous flow of learning from one page to another for comprehending the related topics.

In the beginning of the course, always include an objectives and outcomes section to help students understand the objective of the course. Other information that can be included such as topics and lessons that will be covered, prerequisites knowledge required, assessment involved and skills that would be obtained after completing the module. According to literature [41], who inform that in order to design courses, the course objectives, strategies and technologies 
used for achieving the objectives must be considered. At the end of class, both sides can tally the listed outcomes with the experienced outcomes and judge the course efficacy.

In addition, getting inputs from well-known authors or other senior teachers will enhance the course credibility. By mentioning their contributions would let the students to increase their trust in the lessons taught in the online course. It can be a collaboration for editing notes or a contributed chapter that will be a favour of your online course. Including a variety of course materials sources such as web resources, book chapters, multimedia resources and instructional videos from other authors were very beneficial to online students too [30].

Additionally, there are many ways to improve the engagement aspects of e-Learning and ensure that learners are taking a keen interest. To make students highly engaging, teachers can equip the modules with post-course summary, allow group discussions, build a social media community and conduct assessment after completion of each module. All this effort by the instructor can develop interactivity and collaboration in the online community [41]. Push notifications such as discussion forums, latest events and current affairs for general knowledge also can be sent to promote the courses and engage them in the learning activities.

As a conclusion, e-Learning is full of challenges and opportunities that can create effectiveness in the education environment. For students, this is a way to broaden their educational opportunities and remain competitive in an education field. This online learning environment supports the accessibility of ICT on a large scale in terms of usage and benefits in context of education development.

\section{FINDINGS}

From the three sectors discussed earlier, there are several related strategies used in such criteria as social media usage, including the multimedia elements and reviews or input from users. These similarities are explaining further in Table 4.

Table 4. Similarities of Web Engagement Strategies

\begin{tabular}{|l|c|c|c|}
\hline Category & Social media & Multimedia & Review \\
\hline E-Commerce & Yes & Yes & Yes \\
\hline E-Government & Yes & Yes & Yes \\
\hline Higher Education & Yes & Yes & Yes \\
\hline
\end{tabular}

All sectors take the opportunity of social media platforms such as Twitter, Instagram and Facebook benefits and usage as one of the strategies to get engagement from users. Interesting multimedia elements such as interactive videos are used so that the information can reach the target audiences. Lastly, product or input reviews and feedback according to subjects or services offered also can help to increase user engagement in each sector. All of these similarities will contribute to increased consumer engagement and affect their level of loyalty to services or products.

However, there are some differences in web engagement strategy in each sector because they have different concepts and purpose. Each sector has their own way of engaging the web to ensure their success. For example in business, the content of the business website will contain the latest promotions and advertisements but in the field of education, learning videos should be a priority. While in the government portal, it must contain information related to services and facilities provided to the people. This comparison of web engagement strategies is presented in Table 5.

Table 5. Differences of Web Engagement Strategies in Different Sectors

\begin{tabular}{|c|c|c|c|}
\hline Item & E-Commerce & E-Government & Higher Education \\
\hline Purpose & $\begin{array}{l}\text { Sell and buy products or } \\
\text { services through digital } \\
\text { platforms. }\end{array}$ & $\begin{array}{l}\text { Increase collaboration } \\
\text { between citizens and } \\
\text { government. }\end{array}$ & $\begin{array}{l}\text { Interaction between } \\
\text { academicians and students. }\end{array}$ \\
\hline $\begin{array}{l}\text { Size of user } \\
\text { population }\end{array}$ & Large. & Large. & $\begin{array}{l}\text { Depending on the institution } \\
\text { size / population. }\end{array}$ \\
\hline $\begin{array}{l}\text { Type of } \\
\text { Information } \\
\text { System }\end{array}$ & e-Commerce platform. & Web Portal. & $\begin{array}{l}\text { Learning Management } \\
\text { System. }\end{array}$ \\
\hline Accessibility & Open to all internet users. & Subject to focus group. & $\begin{array}{l}\text { Academic staff and students } \\
\text { of the institution only. }\end{array}$ \\
\hline
\end{tabular}




\section{CONCLUSION}

This paper reviews the various engagement definitions and user interaction in three different sectors. There are a few indicators of website metrics that are most useful in helping to analyze who is visiting the website, how long the content is engaged and which parts of the website are most popular. This web engagement is appreciated very much because it helps to spread the news about any products or services. All the strategies are well explained for each business, government and education sector. For future research, Digital Government that leads to Citizen Centric to strengthen economic and social infrastructure shall be considered. While in the education sector, online engagement framework for higher education can also be included.

\section{ACKNOWLEDGEMENT}

The authors would like to thank UMP for this opportunity to publish this review paper.

\section{REFERENCES}

[1] B. Niket, S. Inchal, A. S. Gaikwad, and A. R. Kapasi, "A Report on Improving Website Content by Measuring Site Engagement," Int. J. Adv. Res. Comput. Commun. Eng., vol. 5, no. 11, pp. 386-390, 2016.

[2] M. Lalmas, H. O’Brien, and E. Yom-Tov, "Measuring User Engagement," Synth. Lect. Inf. Concepts, Retrieval, Serv., vol. 6, no. 4, pp. 1-132, 2015.

[3] J. Wua, J. Shaokun Fan, and L. Zhao, "Understanding and measuring user engagement and attention in online news reading," WSDM 2016 - Proc. 9th ACM Int. Conf. Web Search Data Min., pp. 113-122, 2016.

[4] J. Lehmann, M. Lalmas, E. Yom-Tov, and G. Dupret, "Models of user engagement," Lect. Notes Comput. Sci. (including Subser. Lect. Notes Artif. Intell. Lect. Notes Bioinformatics), vol. 7379 LNCS, pp. 164-175, 2012.

[5] R. D. Mersey, E. C. Malthouse, and B. J. Calder, "Engagement With Online Media,” J. Media Bus. Stud., 2010.

[6] J. Wu, S. Fan, and J. L. Zhao, "Community engagement and online word of mouth: An empirical investigation," Inf. Manag., vol. 55, no. 2, pp. 258-270, 2018.

[7] R. Iqbal, M. Scott, and T. Cleveland, "Measuring actual visitor engagement in news websites," CEUR Workshop Proc., vol. 1618, no. July, 2016.

[8] G. Zheng and S. Peltsverger, "Web Analytics Overview," Encycl. Inf. Sci. Technol. Third Ed., no. January, pp. 7674-7683, 2015.

[9] R. Thakur, "Customer engagement and online reviews," J. Retail. Consum. Serv., vol. 41, no. February 2017, pp. 48-59, 2018.

[10] X. Zheng, C. M. K. Cheung, M. K. O. Lee, and L. Liang, "Building brand loyalty through user engagement in online brand communities in social networking sites," Inf. Technol. People, vol. 28, no. 1, pp. 90-106, 2015.

[11] L. D. Hollebeek and K. Macky, "Digital Content Marketing's Role in Fostering Consumer Engagement, Trust, and Value: Framework, Fundamental Propositions, and Implications," J. Interact. Mark., vol. 45, pp. 27-41, 2019.

[12] M. Mpinganjira, "Influencing consumer engagement in online customer communities: The role of interactivity," Acta Commer. - Indep. Res. J. Manag. Sci., vol. 16, no. 1, pp. 1-10, 2016.

[13] N. F. Ibrahim, X. Wang, and H. Bourne, "Exploring the effect of user engagement in online brand communities: Evidence from Twitter," Comput. Human Behav., vol. 72, pp. 321-338, 2017.

[14] J. Kumar and V. Kumar, "Drivers of brand community engagement," J. Retail. Consum. Serv., no. June, p. $101949,2019$.

[15] R. J. H. Wang, E. C. Malthouse, and L. Krishnamurthi, "On the Go: How Mobile Shopping Affects Customer Purchase Behavior," J. Retail., vol. 91, no. 2, pp. 217-234, 2015.

[16] A. Csikósová, M. Antošová, and K. Čulková, "Strategy in Direct and Interactive Marketing and Integrated Marketing Communications," Procedia - Soc. Behav. Sci., vol. 116, no. 1, pp. 1615-1619, 2014.

[17] S. Sharma, "E-GOVERNMENT IN DIGITAL ERA: CONCEPT, PRACTICE , AND DEVELOPMENT," Int. J. Sci. Technol. Manag., vol. 6, no. 22, pp. 771-777, 2017.

[18] G. Ntulo and J. Otike, “E - GOVERNMENT: ITS ROLE, IMPORTANCE AND CHALLENGES,” pp. 1-16, 2014.

[19] N. Sahari, N. Zainal Abidin, H. Kasimin, and H. Mohd Idris, "Malaysian e-Government application: Factors of actual use," Aust. J. Basic Appl. Sci., vol. 6, no. 12, pp. 325-334, 2012.

[20] T. Lee, B. K. Lee, and S. Lee-Geiller, "The effects of information literacy on trust in government websites: Evidence from an online experiment," Int. J. Inf. Manage., vol. 52, no. February, 2020.

[21] R. M. Ramli, "E-government implementation challenges in malaysia and south korea: A comparative study," Electron. J. Inf. Syst. Dev. Ctries., vol. 80, no. 1, pp. 1-26, 2017.

[22] A. Zarei, M. Hosseini-Shoar, A. Isfandyari-Moghaddam, and M. Hassanzadeh, "E-Government Implementation Models and Presenting," J. Bus. Soc., no. May, 2018.

[23] E. Falco and R. Kleinhans, "Beyond technology: Identifying local government challenges for using digital platforms for citizen engagement," Int. J. Inf. Manage., vol. 40, no. October 2017, pp. 17-20, 2018.

[24] X. Wang and Z. Liu, "Online engagement in social media: A cross-cultural comparison," Comput. Human Behav., vol. 97 , no. May 2018, pp. 137-150, 2019.

[25] R. K. Verma, S. Kumar, and P. V. Ilavarasan, "Government portals, social media platforms and citizen engagement in India: Some insights," Procedia Comput. Sci., vol. 122, pp. 842-849, 2017.

[26] E. Bonsón, D. Perea, and M. Bednárová, "Twitter as a tool for citizen engagement: An empirical study of the Andalusian municipalities," Gov. Inf. Q., vol. 36, no. 3, pp. 480-489, 2019.

[27] P. Redmond, L. A. Abawi, A. Brown, R. Henderson, and A. Heffernan, "An online engagement framework for higher education," Online Learn. J., vol. 22, no. 1, pp. 183-204, 2018.

[28] J. Saltmarsh, E. Zlotkowski, and E. L. Hollander, "Indicators of engagement," High. Educ. Democr. Essays Serv. Civ. 
Engagem., vol. 9781439900, pp. 285-302, 2011.

[29] B. Gilbert, "Online Learning Revealing the Benefits and Challenges," Fish. Digit. Publ. Educ., vol. 4, 2015.

[30] F. (University of N. C. C. Martin and D. U. (University of W. Bolliger, "Engagement Matters: Student Perceptions on the Importance of Engagement Strategies in the Online Learning Environment," Online Learn. J., vol. 22, no. 1, pp. 205-222, 2018.

[31] M. Hu, H. Li, W. Deng, and H. Guan, "Student Engagement: One of the Necessary Conditions for Online Learning," Proc. 5th Int. Conf. Educ. Innov. through Technol. EITT 2016, pp. 122-126, 2017.

[32] J. . Fernández Rodríguez, J. J. Rainer, and F. Miralles, "Essential Features in eLearning: Efficiency and Quality," Pensee, vol. 76, no. 7, pp. 305-314, 2014.

[33] R. P. Bhatia, "Features and Effectiveness of E-learning Tools," Glob. J. Bus. Manag. Inf. Technol., vol. 1, no. 1, pp. 1-7, 2011.

[34] S. Molinillo, R. Aguilar-Illescas, R. Anaya-Sánchez, and M. Vallespín-Arán, "Exploring the impacts of interactions, social presence and emotional engagement on active collaborative learning in a social web-based environment," Comput. Educ., vol. 123, no. May, pp. 41-52, 2018.

[35] A. Aldiab, H. Chowdhury, A. Kootsookos, F. Alam, and H. Allhibi, "Utilization of Learning Management Systems (LMSs) in higher education system: A case review for Saudi Arabia,” Energy Procedia, vol. 160, no. 2018, pp. 731-737, 2019.

[36] P. E. Ramírez-Correa, F. J. Rondan-Cataluña, J. Arenas-Gaitán, and J. L. Alfaro-Perez, "Moderating effect of learning styles on a learning management system's success," Telemat. Informatics, vol. 34, no. 1, pp. 272-286, 2017.

[37] K. M. Williams, R. E. Stafford, S. B. Corliss, and E. D. Reilly, "Examining student characteristics, goals, and engagement in Massive Open Online Courses," Comput. Educ., vol. 126, no. February 2017, pp. 433-442, 2018.

[38] Y. Jung and J. Lee, "Learning Engagement and Persistence in Massive Open Online Courses (MOOCS)," Comput. Educ., vol. 122, no. February, pp. 9-22, 2018.

[39] A. Khamparia and B. Pandey, "Impact of interactive multimedia in E-learning technologies: Role of multimedia in Elearning," Enhancing Acad. Res. With Knowl. Manag. Princ., no. March, pp. 199-227, 2017.

[40] T. Javorcik and R. Polasek, "The Basis for Choosing Microlearning Within the Terms of E-Learning in the Context of Student Preferences," ICETA 2018 - 16th IEEE Int. Conf. Emerg. eLearning Technol. Appl. Proc., no. November, pp. 237-244, 2018.

[41] A. Sun and X. Chen, "Online education and its effective practice: A research review," J. Inf. Technol. Educ. Res., vol. 15, no. 2016, pp. 157-190, 2016. 